DOI: https://doi.org/10.24297/jac.v17i.8714

\title{
Effect of Temperature Extraction on the Potassium and Calcium Content in the Lemon and Orange Water Peel Extracts
}

Amra Bratovcic

\author{
University of Tuzla, Faculty of Technology, Department of Physical Chemistry and Electrochemistry,
}

Urfeta Vejzagica 8, 75000 Tuzla, Bosnia and Herzegovina

amra.bratovcic@untz.ba

\begin{abstract}
The aim of this study is to examine the effect of temperature extraction on the potassium (K) and calcium (Ca) contents in orange and lemon peel extracts. The extractions were done at $62{ }^{\circ} \mathrm{C}$ and $92{ }^{\circ} \mathrm{C}$ for 15 minutes and atmospheric pressure in distilled water. The fruit peel content in the extraction mixture was $5 \%(\mathrm{w} / \mathrm{v})$ in all samples. Calcium ( $\mathrm{Ca}$ ) and potassium $(\mathrm{K})$ concentrations have been determined by flame photometric method. This research has revealed that by increasing the temperature of extraction, in particular, the concentration of $\mathrm{Ca}$ and $\mathrm{K}$ concentrations increased as applied extraction temperatures increased.

The concentration of potassium is higher than the concentration of calcium in orange and lemon extracts, respectively. The concentration of $\mathrm{K}$ was $308 \mathrm{mg} / \mathrm{l}$ at $62{ }^{\circ} \mathrm{C}$ and $361 \mathrm{mg} / \mathrm{l}$ at $92{ }^{\circ} \mathrm{C}$ in lemon extracts, while in orange extracts the concentration of $\mathrm{K}$ was $476 \mathrm{mg} / \mathrm{l}$ at $62{ }^{\circ} \mathrm{C}$ and $483 \mathrm{mg} / \mathrm{l}$ at $92{ }^{\circ} \mathrm{C}$. The concentration of $\mathrm{Ca}$ was $70.8 \mathrm{mg} / \mathrm{l}$ at $62{ }^{\circ} \mathrm{C}$ and $71.9 \mathrm{mg} / \mathrm{l}$ at $92{ }^{\circ} \mathrm{C}$ in lemon extracts, while in orange extracts the concentration of Ca was $91 \mathrm{mg} / \mathrm{l}$ at $62{ }^{\circ} \mathrm{C}$ and $93.6 \mathrm{mg} / \mathrm{l}$ at $92^{\circ} \mathrm{C}$. These results confirm that both citrus could be a very valuable source of potassium and calcium which are needed micronutrients to ensure the water and electrolyte balance and to build and maintain strong bones, proper function of muscles and nerves.
\end{abstract}

Keywords: Orange And Lemon Peel, Water Extracts, Potassium, Calcium.

\section{Introduction}

The European circular economy package (European Commission, Closing loop-An EU action plan Circular Economy, 2015) explicitly aligns to the Sustainable Development Goal 12.3 and made food waste one of its priority areas. Any approach tackling food waste needs to align with sustainable development, making environmental, social and economic sense. Unger and Razza in 2018 suggesting that industry and society should move to circular economy models. Sweet orange (Citrus aurantium) is a very well known fruit, widely available in countries around the world. Although, sweet orange is the major fruit in this group constituting $\sim 70 \%$ of the total citrus production and consumption.

Other citrus fruits, such as tangerine or mandarin (Citrus Reticulata), grapefruit (Citrus Vitis), lime (Citrus Aurantifulia), and lemon (Citrus Limonum) are also grown and consumed extensively (Okwi \& Emenike, 2006; Sharma et al., 2017). The citrus processing industry yearly generates tons of residues, and orange peel is the primary waste fraction, from the extraction of citrus juice in industrial plants. The amount of world industrial waste of citrus is estimated at $15 \times 10^{6}$ tons (Marin et al., 2007). The management of these wastes, which produce odor and soil pollution, represents a major problem for the food industry (Ma et al., 1993). However, numerous studies have shown that orange peel can be further used to produce citric acid (Torrado et al., 2011) or even pyrolyzed orange peels as solid biofuels and biosorption of heavy metals (Santos et al., 2015).

This waste is rich in sugars, fibers, organic acids, amino acids and proteins, minerals calcium and magnesium, oils, lipids, and large amounts of flavonoids and vitamin A, vitamin B, vitamin C (Braddock, 1999) which are a 
powerful antioxidant and may help to protect cell damage (Bratovcic, 2020). Therefore, citrus wastes are of immense economic value as it contains abundant amounts of various essential compounds. The composition of citrus fruits is affected by several factors, such as variety, growth, maturity stage and climatic conditions of that particular region (Salunkhe \& Kadam, 1995). Calcium and potassium are minerals micronutrients that the body needs in smaller amounts. The fruit peel extracts may be further encapsulated, as recently has been reported by Bratovcic and Suljagic in 2019. The ratio of calcium to potassium is called the thyroid ratio and when it is not good, the thyroid gland does not work properly.

Four major minerals help regulate thyroid and adrenal function. These are calcium, magnesium, sodium and potassium. The normal level for each of these minerals is expressed in milligrams or percentages - for calcium it is 40 , magnesium 6, sodium 25 and potassium 10. Potassium is involved in the regulation of the water and electrolyte balance and the acid-base balance in the body (Pohl et al., 2013; Stone et al., 2016). Calcium is an essential nutrient that is necessary for many functions in human health. Calcium is the most abundant mineral in the body with $99 \%$ found in teeth and bone. Only $1 \%$ is found in the serum. Calcium is involved in vascular contraction, vasodilation, muscle functions, nerve transmission, intracellular signaling and hormonal secretion (Beto, 2015). Lactose intolerance may determinate calcium malabsorption or may decrease calcium intake by the elimination of milk and dairy products.

The diet is characterized by food containing a high amount of calcium, potassium, magnesium and low amount of sodium. If it is impossible to reach the requirement with only diet, it is needed the supplement of calcium and vitamin D. Some drugs may interfere with calcium and other nutrients and produce an unfavorable effect on bone health (Miggiano \& Gagliardi, 2005). The white inner part between the skin and the fruit can be consumed. It is sour or bitter but it contains more vitamin $C$ than the fruit itself with a good deal of fiber. The bitter taste is the result of many flavonoids that orange peel contains. Flavonoids in orange peels have several anti-cancer effects. Global production of citrus fruit has significantly increased during the past three years. According to the Food and Agriculture Organization of the United States (FAO), the world orange production in 2017 was 17218 173, while lemons and limes were 73313089 tonnes.

Recent research carried out by Czech et al., 2020 have revealed the greatest difference between pulp and peel was observed in pomelo and orange, as the peel of these two fruits was nearly seven and five times richer in this macronutrient than the pulp. Nutrients found in lemon (Citrus limon) peel specifically polyphenols, can help to manage blood glucose levels and improve insulin resistance. Health benefits of orange peel include: improves digestion, speeds up metabolism, helps in weight loss, strengthens the immune system, helps prevent cancer, improves oral health, beneficial for skin, good for diabetes. Based on all of the above, orange is a great source of nutrients, essential for overall health, as well as their peels, are equally important to include in everyday diet.

Research has shown that adequate calcium intake can reduce the risk of fractures, osteoporosis, and diabetes in some populations. The study aimed to investigate the influence of temperature on calcium and potassium contents in orange and lemon peel extracts, as well as to compare the mineral content between the citrus peel extracts and to determine which citrus fruit, among orange and lemon is the richest in examined minerals.

\section{Materials and Methods}

About $10 \mathrm{~kg}$ of fresh oranges and $5 \mathrm{~kg}$ of fresh lemons were collected in February 2018. The fruits were purchased at the same supermarket in Tuzla in Bosnia and Herzegovina. The origin of citrus fruits were from Spain. The goal of the author was to determine the concentrations of calcium and potassium and the information about cultivar is missing. Fruit peel extracts were collected after consuming a certain type of fruit. The fruit was washed with the tap water before consumption. Each fresh fruit peel after consumption was weight and then cut in small pieces and dried in the air for seven days. After air drying, the samples were ground in a grinder $A D$ 443, Adler Europe, $150 \mathrm{~W}$, then the same sample was weight and the free water percentage was determined. 


\section{Determination of free water}

Free water is a part of total water, which evaporates at room temperature. The amount of each sample taken for air drying was $100 \mathrm{~g}$. The previously weighed wet samples were left for drying at room temperature about $25{ }^{\circ} \mathrm{C}$. Experimental data confirm that seven days of drying of the samples at room temperature were enough that the mass of the samples no longer change and remain constant.

From the mass data obtained before and after drying was possible to estimate the percentage of free water by using the following equation:

$\%$ free water $=\frac{a-b}{a} \times 100$

where:

a - mass of the sample in gram before drying

$b$ - mass of the sample in gram after drying.

The drying of the sample has been done because of the stability of the samples in the dried state. During drying process, each piece of the sample were separated, because the formation of moist were observed when the pieces of fruit peels were overlapped. The final goal is to use air-dried fruit peels as the source of $\mathrm{Ca}$ and $\mathrm{K}$.

\section{pH and conductivity measurements}

$\mathrm{pH}$ measurements were done by $\mathrm{pH}$ Meter Mettler Toledo MP220 and glass $\mathrm{pH}$ electrode Hanna Instruments HI $1053,0-12 \mathrm{pH}$, temperature -5 to $70{ }^{\circ} \mathrm{C}$ in prepared fruit peel extracts, while conductivity measurements were done by conductometer Mettler Toledo MPC $227 \mathrm{pH} /$ conductivity meter equipped with the electrode for conductivity measurements - Metler Toledo InLab 730 NTC, $0 \ldots .1000$ mS, $0 \ldots 100{ }^{\circ} \mathrm{C}$.

\section{Determination of potassium and calcium}

Potassium analysis was performed by the plant-available phosphorus $(\mathrm{P})$ and potassium $(\mathrm{K})$ extracted by ammonium lactate (AL) solution (Egner-Riehm-Domingo method) (Egnér et al., 1960). The principle of the method is based on the extraction of potassium by an $\mathrm{AL}$ solution, which in chemical composition is $0.1 \mathrm{~mol} / \mathrm{l}$ ammonium -lactate $\left(\mathrm{CH}_{3} \mathrm{CHOHCOONH} 4\right)$ and $0.4 \mathrm{~mol} / \mathrm{l}$ ethanoic acid $\left(\mathrm{CH}_{3} \mathrm{COOH}\right)$. This AL solution desorb $\mathrm{K}^{+}$ ions from the sorption complex from the orange or lemon peel filtrate extracts.

In the extract filtrate, potassium is determined directly by flame photometry. Prepared standards are used to determine the potassium concentration. The standards are read on a flame photometer and a calibration curve is made, followed by plant extract filters. The potassium and calcium were determined by a flame photometric method with Microprocessor flame photometer, Labtronics AN ISO 9001:2008 certified company model LT671.

\section{Chemicals}

Calcium carbonate $\left(\mathrm{CaCO}_{3}\right)$ was purchased from PanReac Quimica SLU (Barcelona, Spain) and potassium chloride $(\mathrm{KCl})$ was procured from Lachner (Neratovice, Czech Republik). All chemicals and solvents used were of analytical grade.

\section{Preparation of basic standard solution for potassium}

$0.5 \mathrm{~g}$ of potassium chloride was previously dried for 2 hours at $105^{\circ} \mathrm{C}$ and then dissolved in 1 liter of distilled water. Five standard solutions for the potassium calibration curve were prepared in the concentration range 
from $0-20 \mathrm{mg} / \mathrm{l}$. The standard solutions consist of basic standard solution $0.5 \mathrm{~g} / \mathrm{l}$ and $10 \mathrm{ml}$ of AL working solution.

\section{Preparation of AL working solution}

$275.48 \mathrm{ml}$ of lactic acid with 0.66 I of distilled water were put in volumetric flask of 1 liter and left in the oven at $96{ }^{\circ} \mathrm{C}$. After 48 hours, the distilled water was added on it. Then, $837.43 \mathrm{ml}$ of this prepared solution were mixed with $577 \mathrm{ml}$ of $99 \%$ acetic acid. In this solution were added $256.6 \mathrm{~g}$ of ammonium acetate and then were diluted up to 3.3 liter with distilled water.

\section{Basic standard solution for calcium}

$1000 \mathrm{mg} / \mathrm{l}: 0.624 \mathrm{~g} \mathrm{CaCO}_{3}$ was dissolved in a mixture of $\mathrm{HCl}$ and distilled water in a ratio, 1:1 and diluted to $250 \mathrm{ml}$. From basic standard solution, $1000 \mathrm{mg} / \mathrm{l}$, was prepared $100 \mathrm{mg} \mathrm{Ca} / \mathrm{l}$, and then a series of standard solutions. The total number of standard solutions was 10 and they were prepared in $100 \mathrm{ml}$ in the concentration range from $10-100 \mathrm{mg} / \mathrm{l}$.

\section{Preparation of orange and lemon peel extracts}

In $100 \mathrm{ml}$ of distilled water $5 \mathrm{~g}$ of air-dried orange/lemon peel was added and was heated to $62{ }^{\circ} \mathrm{C}$ and $92{ }^{\circ} \mathrm{C}$ and stirred at $500 \mathrm{rpm}$ and kept for $15 \mathrm{~min}$ to make an extraction. Then, the samples were filtered through Whatman filter paper LGG-Plain disc filter, qualitative, very slow. The extracts prepared in this way were stored at $4{ }^{\circ} \mathrm{C}$ until further use. The names were given to samples by following weight percent w\%, the initial letter of fruit and temperature: $5 \% \mathrm{~N} 62 \mathrm{C}$ and $5 \% \mathrm{~N} 92 \mathrm{C}$; and $5 \% \mathrm{L62C}$; and \% $\mathrm{L} 92 \mathrm{C}$, respectively.

\section{Results and Discussion}

In Fig. 1 is shown the appearance of the air dried orange and lemon peel samples. In a previous section under materials and methods the explanation of the procedure of preparation of samples are in detail described. These solid orange and lemon peels were used for the preparation of water peel extracts.

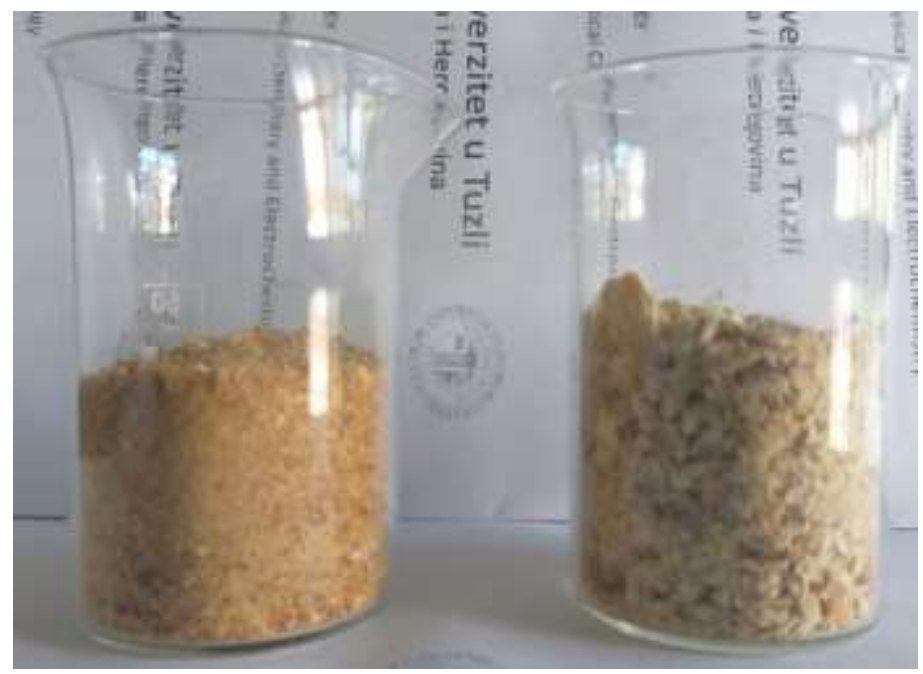

Figure 1. Air-dried orange and lemon peel samples.

In Table 1 are shown the experimental results of mass \% of free water in orange and lemon peels. The procedure of determination of the mass $\%$ of free water in orange and lemon peels were previously described in detail. 
Table 1. Mass \% of free water in orange and lemon peels.

\begin{tabular}{|l|l|l|}
\hline Number of samples & $\begin{array}{l}\text { Mass \% free } \\
\text { water } \\
\text { orange peel }\end{array}$ & $\begin{array}{l}\text { Mass \% free } \\
\text { water in lemon } \\
\text { peel }\end{array}$ \\
\hline 1 & 73.1 & 76.3 \\
\hline 2 & 73.5 & 75.9 \\
\hline 3 & 74.2 & 74.5 \\
\hline 4 & 72.8 & 76.3 \\
\hline 5 & 70.7 & 77.5 \\
\hline $\begin{array}{l}\text { Average mass \% of free } \\
\text { water }\end{array}$ & 72.86 & 76.1 \\
\hline
\end{tabular}

From Table 1 is noticeable that fruit peel contain about 70 mass \% of free water and $30 \%$ of solid material. The solid part of orange and lemon were used for the preparation of water peel extracts.

In Table 2 the experimental results of the $\mathrm{pH}$ and electrical conductivity are shown.

Table 2. Values of $\mathrm{pH}$ and conductivity of lemon and orange extracts.

\begin{tabular}{|l|l|l|}
\hline Sample & $\mathrm{pH}$ & $\begin{array}{l}\text { Electrical } \\
\text { conductivity } \\
(\mu \mathrm{S} / \mathrm{cm})\end{array}$ \\
\hline lemon & 3.50 & 1938 \\
\hline orange & 3.92 & 1023 \\
\hline
\end{tabular}

The results of $\mathrm{pH}$ (Table 2) indicate that both extracts are weakly acid. The $\mathrm{pH}$ value of lemon extract is 3.5 and the $\mathrm{pH}$ value of orange extract is 3.92. In recent research carried out by Bratovcic et al., 2018 were studied the physical-chemical properties and stability of orange juice at room temperature. The results have shown that the $\mathrm{pH}$ of squeezed orange juices with and without pulp was 3.2. This result indicates that the $5 \%$ orange peel extracts give more alkaline $\mathrm{pH}$ which is 3.92 compared to squeeze orange juice. This result may be explained by the different chemical composition of the pulp and peel fruits.

The conductivity values of the orange and lemon peel extracts were lower $(1.023$ and $1.938 \mathrm{mS} / \mathrm{cm})$ than in squeeze orange juice $(3.37 \mathrm{mS} / \mathrm{cm})$. It is possible to assume that the presence of distilled which is not a good conductor of electricity and consequently gives lower conductivity values.

\section{Determination of potassium and calcium}

In Figs. 2-3 are presented the concentrations of calcium and potassium in $5 \mathrm{w} / \mathrm{v}$ of orange and lemon water peel extracts determined by the previously described method. 
In Fig. 2 are shown the concentration of calcium and potassium in $5 \% \mathrm{w} / \mathrm{v}$ of orange water peel extracts.

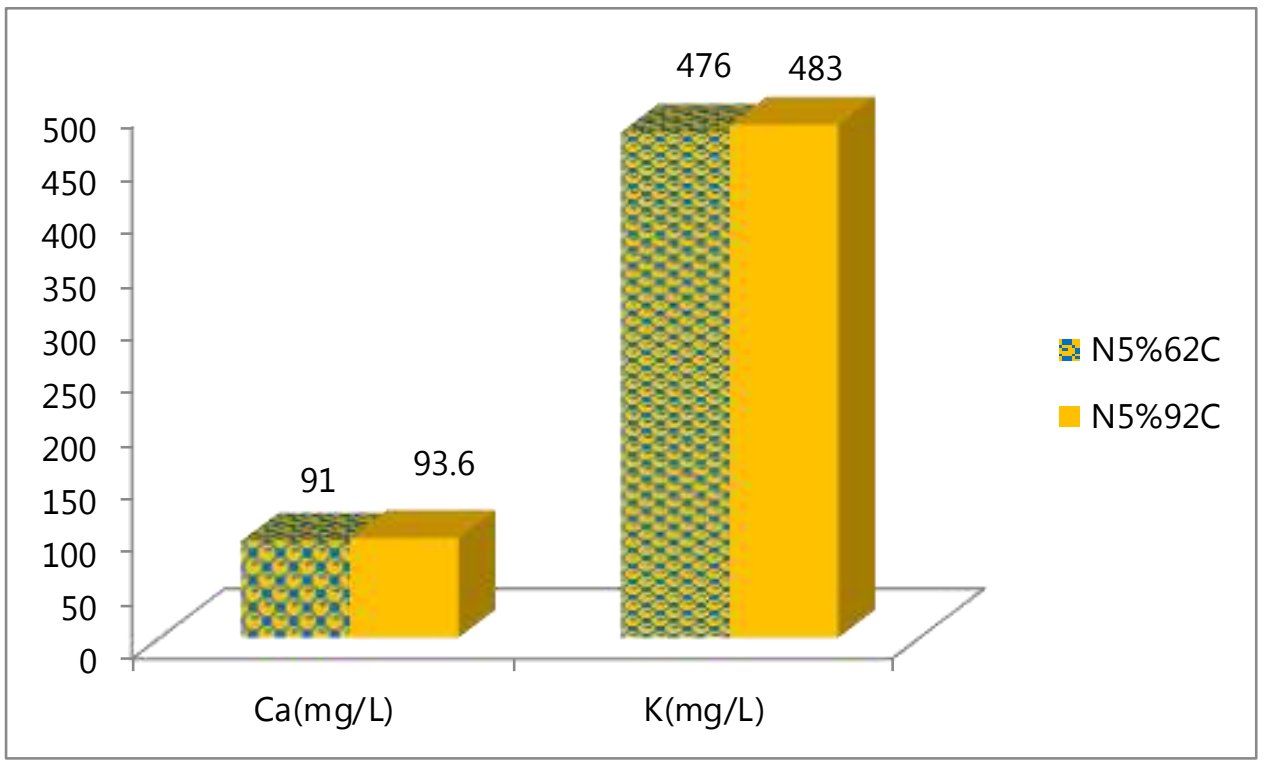

Figure 2. The concentration of calcium and potassium in $5 \% \mathrm{w} / \mathrm{v}$ of orange water peel extracts at 62 and $92{ }^{\circ} \mathrm{C}$.

From Fig. 2 is possible to note that the concentration of potassium in orange peel extracts is higher than the concentration of calcium. These results are in line with the raw nutrition facts of orange peel, where the concentration of calcium is $161 \mathrm{mg} / 100 \mathrm{~g}$ and potassium $212 \mathrm{mg} / 100 \mathrm{~g}$ (NutritionValue.Org. available on: https://www.nutritionvalue.org/Orange_peel\%2C_raw_nutritional_value.html). By increasing the temperature of extraction, the concentration of calcium and potassium slightly increases.

In Fig. 3 are shown the concentration of calcium and potassium in 5\%w/v lemon water peel extract.

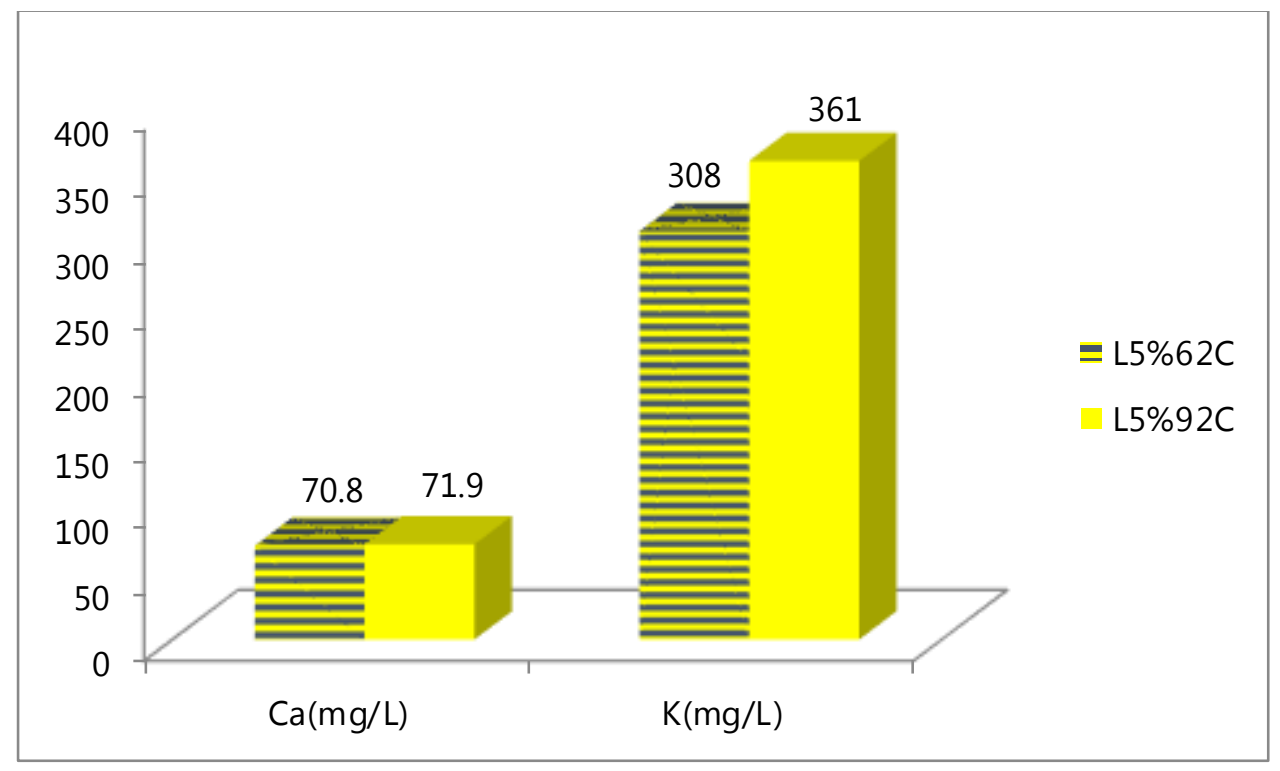

Figure 3. The concentration of calcium and potassium in $5 \% \mathrm{w} / \mathrm{v}$ of lemon water peel extracts at 62 and $92{ }^{\circ} \mathrm{C}$.

From Fig. 3 is clear that the concentration of potassium in lemon peel extracts is higher than the concentration of calcium. These results are in line with the raw nutrition facts of lemon peel, where the concentration of calcium is $134 \mathrm{mg} / 100 \mathrm{~g}$ and potassium $160 \mathrm{mg} / 100 \mathrm{~g}$. 
It is evident that by increasing the temperature of extraction the concentration of calcium slightly increase, while the higher concentration of potassium is more pronounced at higher temperature.

From Figs. 2 and 3 is possible to note that the concentration of potassium and calcium is higher in orange peel extracts, then in lemon peel extracts. This research reveals higher potassium and calcium content in oranges, which is in accordance with studies carried out by two different research groups (Baghurst et al., 2003; Liu et al., 2001). By increasing the temperature, the concentration of potassium is increased for $7 \mathrm{mg} / \mathrm{l}$ in orange peel extract, while in lemon peel extract is increased for $53 \mathrm{mg} / \mathrm{l}$, while the concentration of calcium does not change significantly. Therefore, the influence of temperature extraction on potassium concentration is more evident than for calcium content. The results can help establish dietary guidelines for people suffering from potassium deficiency, as well as for lactating women, whose potassium requirement is higher, at about $5.1 \mathrm{~g} / \mathrm{d}$ (Otten et al., 2006). The recommended daily intake (RDI) of calcium is $1000 \mathrm{mg}$ per day for most adults, though women over 50 and everyone over 70 should get $1200 \mathrm{mg}$ per day, while children aged 4-18 are advised to consume $1300 \mathrm{mg}$ (Jennings, 2018).

\section{Conclusions}

In this paper, the assessment of temperature extraction on potassium and calcium contents in orange and lemon water peel extracts were done. Generally, the results indicate that by increasing the temperature of extraction from 62 to $92{ }^{\circ} \mathrm{C}$ the concentration of potassium is increased, while the concentration of calcium was almost constant. There is a small influence of temperature extraction on the concentration of both elements, but not significant. The results suggest that is better to make an extraction of citrus peel extracts at lower temperature considering that there are no significant changes in the concentration of examined minerals as well as from the point of saving energy and cost. The results have shown that orange peel extracts contain higher concentrations of potassium and calcium than lemon peel extracts. However, by increasing the temperature of extraction, increasing the concentration of potassium in lemon extracts is much more evident. According to the experimental results, the quantities of calcium and potassium indicate that lemon and orange peel extracts could be valuable sources of examined minerals. Lemon and orange peel could be employed as a functional food and become a significant source of micronutrients in the pharmaceutical industry for the production of mineral preparations in the form of tea or tablets with a high content of calcium and potassium. In future, this research is going to be extended to the study of the antioxidant capacity of the orange and lemon peel extracts. This may be one of the ways of the move towards a circular economy model relating to sustainable development, making environmental, social and economic sense.

\section{Conflicts of Interest}

The author declares no conflict of interest.

\section{Funding Statement}

Author state that the research described in this article was funded by author.

\section{References}

1. Baghurst, Katrine \& CSIRO. Health Sciences and Nutrition \& Horticulture Australia (2003). Update of citrus health benefits literature review. Horticulture Australia, Sydney

2. Beto, J.A. (2015). The role of calcium in human aging. Clinical Nutrition Research. 4, 1-8. https://doi.org/10.7762/cnr.2015.4.1.1

3. Braddock R.J., Handbook of citrus by-products and processing technology (1999). Inc New York; John Wiley \& Sons: 1-247 
4. Bratovcic, A. (2020). Antioxidant Enzymes and their Role in Preventing Cell Damage. Acta Scientifci Nutritional Health, 4(3), 01-07. https://doi.org/10.31080/asnh.2020.04.0659

5. Bratovcic, A., \& Suljagic, J. (2019). Micro- and nano-encapsulation in food industry. Croatian Journal of Food Science and Technology, 11(1), 113-121. https://doi.org/10.17508/cjfst.2019.11.1.17

6. Bratovcic, A., Odobasic, A., Sestan, I., Tucic, E., Hasanbasic, A. \& Saric, E. (2018). Determination of physicalchemical properties and stability of orange juice at room temperature, Sixth international scientific conference "June 5th - World environment day", 76-88.

7. Czech, A., Zarycka, E., Yanovych, D., Zasadna, Z., Grzegorczyk, I., \& Kłys, S. (2020). Mineral Content of the Pulp and Peel of Various Citrus Fruit Cultivars. Biological Trace Element Research. https://doi.org/10.1007/s12011-019-01727-1

8. Egnér, H., Riehm, H., \& Domingo, W. R. (1960). Untersuchungen über die chemische Bodenanalyse als Grundlage für die Beurteilung des Nährstoffzustandes der Böden. II. Chemische Extraktionsmethoden zur Phosphor- und Kaliumbestimmung. Kungliga Lantbrukshögskolans Annaler.

9. European Commission, Closing loop-An EU action plan Circular Economy, Communication from the Commission to the European Parliament, the Council, the European Economic and Social Committee and the Committee of the Regions, C.O.M. 0614, 2015.; available on: https://eur-lex.europa.eu/legalcontent/EN/TXT/?uri=CELEX\%3A52015DC0614

10. Food and Agriculture Organization of the United Nations, available on 27.12.2019. http://www.fao.org/faostat/en/\#data/QC

11. Jennings, K. A. (2018) Top 15 Calcium-Rich Foods (Many Are Non-Dairy). Healthline, available on 27.12.2019. https://www.healthline.com/nutrition/15-calcium-rich-foods

12. Liu, Y., Ahmad, H., Luo, Y., Gardiner, D.T., Gunasekera, R.S., McKeehan, W.L., \& Patil, B.S. (2001). Citrus pectin: characterization and inhibitory effect on fibroblast growth factor-receptor interaction. Journal of Agricultural and Food Chemistry, 49, 3051-3057; https://doi.org/10.1021/jf001020n

13. Ma, E., Cervera, Q., \& Mejía Sánchez, G. M. (1993). Integrated utilization of orange peel. Bioresource Technology. 44, 61-63. https://doi.org/10.1016/0960-8524(93)90209-T

14. Marín, F. R., Soler-Rivas, C., Benavente-García, O., Castillo, J., \& Pérez-Alvarez, J. A. (2007). By-products from different citrus processes as a source of customized functional fibres. Food Chemistry. 100, 736-741. https://doi.org/10.1016/j.foodchem.2005.04.040

15. Miggiano G.A., \& Gagliardi L., (2005) Diet, nutrition and bone health. La Clinica Terapeutica. 156, 47-56. Available on: https://www.ncbi.nlm.nih.gov/pubmed/16080661

16. NutritionValue.Org, Nutrition facts Product: Orange peel raw, available on 27.12.2019. https://www.nutritionvalue.org/Orange peel\%2C raw nutritional value.html

17. Okwi, D.E \& Emenike, I.N. (2006). Evaluation of the phytonutrients and vitamins contents of citrus fruits. Int. J. Mol. Med. Adv. Sci. 2, 1-6; available on: https://medwelljournals.com/abstract/?doi=ijmmas.2006.1.6

18. Otten, J. J., Hellwig, J. P., \& Meyers, L. D. (2006). Part III: Vitamins and Minerals: Thiamin Dietary Reference Intakes. In Dietary Reference Intakes: The Essential Guide to Nutrient Requirements. https://doi.org/10.17226/11537 
19. Pohl, H. R., Wheeler, J. S., \& Murray, H. E. (2013). Sodium and Potassium in Health and Disease. https://doi.org/10.1007/978-94-007-7500-8 2

20. Salunkhe D.K., \& Kadam S.S. (1995). Handbook of fruit science and technology. Production, composition, storage and processing. CRC press; 1-632. Available on: https://www.routledge.com/Handbook-of-FruitScience-and-Technology-Production-Composition-Storage/Salunkhe-Kadam/p/book/9780824796433

21. Santos, C. M., Dweck, J., Viotto, R. S., Rosa, A. H., \& de Morais, L. C. (2015). Application of orange peel waste in the production of solid biofuels and biosorbents. Bioresource Technology. 196, 469-479. https://doi.org/10.1016/j.biortech.2015.07.114

22. Sharma, K., Mahato, N., Cho, M. H., \& Lee, Y. R. (2017). Converting citrus wastes into value-added products: Economic and environmently friendly approaches. Nutrition. 34, 29-46. https://doi.org/10.1016/j.nut.2016.09.006

23. Stone, M. S., Martyn, L., \& Weaver, C. M. (2016). Potassium intake, bioavailability, hypertension, and glucose control. Nutrients. 8, 444. https://doi.org/10.3390/nu8070444

24. Torrado, A. M., Cortés, S., Salgado, J. M., Max, B., Rodríguez, N., Bibbins, B. P., ... Domínguez, J. M. (2011). Citric acid production from orange peel wastes by solid-state fermentation. Brazilian Journal of Microbiology. 42, 394-409. https://doi.org/10.1590/S1517-83822011000100049

25. Unger N., \& Razza F. (2018) Food Waste Management (Sector) in a Circular Economy. In Benetto, E., Gericke K., Guiton M. (eds.), Designing Sustainable Technologies, Products and Policies. Springer, Cham. 127-132, https://doi.org/10.1007/978-3-319-66981-6 15 